\section{Work for the Decision Makers Literature Reviews as a High-Impact Service}

\section{Dustin Fife and Mary Naylor}

Dustin Fife (d.t.fife@gmail.com) is Outreach Librarian and Mary Naylor (mary.naylor@uvu.edu) is Reference/Instruction Librarian at Utah Valley University Library, Orem, Utah.

Correspondence concerning this column should be addressed to Marianne Ryan, Associate University Librarian for User Service Strategies, Northwestern University, 1970 Campus Drive, Evanston, IL 60208; email:marianne-ryan@northwestern.edu.
For academic libraries to thrive, they must continue to find new ways to be relevant to their campus communities. In this column, Dustin Fife and Mary Naylor describe the Utah Valley University Library's recent introduction of research services for campus administrators and decision makersconstituents who often are not directly served by campus libraries. This relatively new service already has facilitated increased access to university leaders and provided additional insight into academic affairs. As importantly, it has paid dividends for the library and librarians by raising awareness of what they have to offer.-Editor

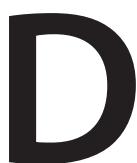

uring the fall of 2014, a senior vice president at Utah Valley University (UVU), a large public institution, asked the library staff to do a literature review for the department of Academic Affairs about high-impact teaching practices in universities. A small group of librarians took on this assignment. They scoured the literature, put together a table that highlighted conclusions for each source, wrote a short summary, submitted it to an appreciative campus decision maker, and discovered a completely new role for the UVU Library.

During the past year, a small team of two librarians and one research assistant completed sixteen literature reviews for various campus partners. These partners include senior vice presidents, associate vice presidents, the Faculty Senate, the Office of Teaching and Learning, and the Department of Academic Affairs. The literature reviews have touched on many different topics, among them open educational resources, undergraduate research, first-generation students, quantitative literacy, and local voting demographics. They were all done for groups involved in highly impactful campus-wide decision making or with new campus initiatives.

The literature review research, including some direct quotes, has appeared in campus white papers, university presentations, administrative addresses, and other visible outlets. More importantly, this service has provided a connection to top campus administrators who often have very little to do with the library, and it supports them in a way that demonstrates the professional value and abilities of librarians.

\section{BACKGROUND}

In the early 2000s, some University of Michigan librarians formalized an Executive Research Service (ERS), which focused on proactive research assistance for University executives (Downing et al. 2011). Downing, Desai, and 
MacKintosh highlighted three findings that the UVU Library experience confirms. First, they found that their ERS was an effective way to show the value of libraries and librarians to decision makers. "The Service also provides valuable opportunities to show executive officers the depth and range of the campus library and librarians' knowledge and expertise." Second, they found that their research service provided incredible insight into campus affairs. "It also provides the Library with insight into the pressing issues and work of our campus executive officers in ways that would otherwise be hidden to us." Last, they found that this service created an important connection with campus decision makers. "Finally, the service provides valuable links between the campus administration and the Library, and provides many opportunities for the Library and librarians to collaborate on projects and programs beyond what might otherwise be available."' In less than a year, the UVU Library experienced all of these findings. The two major examples that are shared in detail in this article show how the UVU Library gained greater access to administrators, acquired insight into future programs and projects, and elevated the stature of librarians in campus life.

\section{THE PROCESS}

Utah Valley University Library's administrative team helped develop this new service and has been supportive with time and resources. First and foremost, administrators helped define who this new research service was for. Though the library has subject librarians that can help faculty and students with their personal research, the literature review team was created to focus on campus organizations, decisions, and initiatives-not on individual research. The library administration team helped define expectations and, more importantly, create sufficient resources for the new service to succeed by amending the job descriptions of two librarians and hiring a research assistant. By limiting the scope of the service to campus initiatives and groups, the library administrative team helped control the amount of work done by the librarians.

This new service has evolved through the process of trial and error. The library team did not wait for procedures to be perfectly laid out and assessed. The team went through a fast-prototyping phase that made the strengths and weaknesses of the service readily apparent.

The process utilized by the actual literature review team includes several steps. It is important to always communicate that the librarians are not subject specialists in these areas, but are adept at finding and evaluating resources. Requests for literature reviews come directly to one of the librarians; they are often vague, requiring a traditional reference interview to gather more information about the requester's needs. Requesters are instructed to articulate their needs in the form of research questions. This allows all parties to know exactly what information is being sought. Communication is essential and making sure that there is documentation for requests limits confusion and saves time for everyone involved.

The team builds the literature reviews in Google Docs, allowing for simultaneous editing and virtual collaboration. The literature review is laid out in sections: research question, executive summary, search terms, a table of peer-reviewed sources (sometimes organized around different questions, depending on the review), and a table of trade sources (when appropriate). The tables have five columns: citations, abstracts, links, limitations, and conclusions. This structure allows for easy access to the most important information. The executive summary synthesizes overall trends from all of the sources. The conclusions column allows stakeholders to read the important points from individual sources without having to read hundreds of pages.

This is time-intensive work, and the timeframe is usually dictated by the requester. These documents are often more than 100 pages long and can include dense scholarly sources. Literature reviews are often requested prior to particular events or presentations, so meeting firm deadlines is critical. The current team at UVU has many other duties and, though this work usually fits into their calendars, there have been instances where conflicting duties made for challenging schedules.

\section{EXAMPLES}

During the fall of 2015, two literature reviews in particular demonstrated how impactful this service has been. The first literature review was requested by the vice president of the Office of Teaching and Learning (OTL). It was a comprehensive overview of how open educational resources (OER) are being used at universities. When completed, the report was over 130 pages long and included more than forty sources, though many more were reviewed. This report was well received; it created a connection between the two departments that is still evolving and highlighted projects that both departments have pursued collaboratively and individually.

Since completing the OER literature review, the library and OTL have organized an OER Symposium and OER Ideas Fair; they also have presented to the college deans and hosted an OER consultation event with Lumen Learning, a company that helps faculty set up and adopt OER. Each of these events was created to support faculty in the adoption of OER. These events have been institutionally supported and well attended. OTL has used the information from the literature review to support other training for faculty. Additionally, the library was inspired to create a pilot project through which they are incentivizing five faculty members with small stipends to adopt OER. The library and OTL have set a goal of "20 by 2020," focused on getting twenty of the most-enrolled general education courses to adopt OER resources by 2020 .

The second literature review was requested by a faculty group that is focused on increasing inquiry-based learning 


\section{MANAGEMENT}

on campus. This review, which focused on how undergraduate research, scholarship, and creative activities are being used at universities across the United States, was 110 pages long and included more than fifty sources. The research was integrated into a campus white paper, which is being used to justify and institutionalize new faculty-led programs.

The executive summary, written for the literature review, was incorporated into the white paper and the library team became co-authors of the project. Librarians are now being included as the project moves forward from an implementation and systems perspective. This is more important than it might seem. At Utah Valley University, librarians are not faculty. This project, however, demonstrates how librarians can contribute to a faculty-driven project at an incredibly high level. The library's technical services librarian is helping with the creation and management of the project's website, and the authors of this paper have been invited to join the implementation team.

Not all literature reviews have led to such sustained collaboration. The connection and impact is tangible from the team's effort, but often the review is the end of the library's direct involvement.

\section{CONCLUSIONS}

Both of these examples are indicative of the value of the UVU research service overall. This new effort has provided the library and librarians with significant opportunities. Conducting the literature reviews has informed the library about upcoming campus programs and initiatives. The service gives the library access to campus administrators and decision makers, and those administrators are now more likely to reach out to librarians with questions large and small. It also has led to librarians being more involved in major campus programs. Because librarians helped with the research, they have, on several occasions, been invited to continue contributing to ongoing programs. Administrators and other groups have consistently praised the work of the librarians and returned to take advantage of the service again.

Literature reviews have been a recent and fruitful addition to services at Utah Valley University Library. They have raised the visibility and impact of the library, while serving important new patrons who will make decisions that affect the library's future. This new research service is a model that may be worth considering by other academic libraries on both large and small campuses.

\section{Reference}

1. Karen Downing, Shevon Desai, and Pamela MacKintosh, "Helping the Hand That Feeds You: Supporting the Research Needs of Campus Executive Officers" (paper presented at the meeting of the American College and Research Libraries, Philadelphia, PA, 2011), accessed May 15, 2015, www.ala.org/acrl/sites/ala.org acrl/files/content/conferences/confsandpreconfs/national/2011/ papers/helping_hand.pdf. 